\title{
Homenaje en la Cámara de Diputados
}

\author{
RENDIDO POR EL DIPUTADO ADAN PUENTE A LA \\ UNIVERSIDAD PENQUISTA, EN LA PERSONA DE DON \\ ENRIQUE MOLINA
}

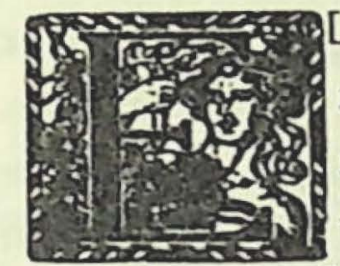

DIPUTADO por Concepción, don Adán Puente Gómez, rindió un sentido homenaje a don Enrique Molina Garmendia, Rector Honorario Vitalicio de la Unila Cámara de Diputados y cuyo texto es el siguiente:

El señor Carmona (Vicepresidente).-Tiene la palabra el Honorable señor Puente, don Adán.

El señor Puente (don Adán).-Señor Presidente, durante los días 27, 28 y 29 del mes de abril, Concepción y el país entero vivieron instantes de expectación, a la vez que de regocijo, por el acto que se desarrollaba en la Universidad de esa legendaria ciudad para dirimir una contienda de carácter nacional que tenía por objeto la elección de su nuevo Rector.

Fue así como durante el transcurso de los días señalados, la atención de Concepción y del país entero estuvo atenta al desenlace del acto al cual me refiero.

19-Atenea N.・ 376 
Señor Presidente, dos eminentes catedráticos postulaban al cargo que hasta ese momento desempeñara don Enrique Molina, los señores Avelino León y Rolando Merino. Durante dos días esos candidatos estuvieron bregando por lograr el beneplácito de los componentes del Claustro Pleno de la Universidad de Concepción y obtener tan honrosa designación. Dos días estuvieron, pues, en el tapete de la actualidad. Sin embargo, sus diferencias no pudieron ser superadas ya que ambos postulantes obtuvieron el $50 \%$ de los votos, sin que pudieran lograr el quórum necesario para decidir la elección a su favor. Entonces, al tercer día de esta contienda, el 29 de ese mes, surgió el nombre del señor David Stitchkin, a quien en definitiva le correspondió el alto honor de ser designado Rector de esa Universidad.

Este hecho tan altamente significativo para la ciudad de Concepción y el país entero, me llena de orgullo, pues me ha correspondido a mí alzar mi voz en esta alta Corporación para rendir un homenaje muy sincero a la persona del ex Rector, don Enrique Molina, que durante 37 años actuó al frente de este gran plantel educacional, orgullo del país y del continente sudamericano.

Señor Presidente, mi modesta condición no me permitió pisar nunca los estrados de este establecimiento educacional. No conozco, por lo tanto, en detalle las actividades de la Universidad de Concepción. Sin embargo, he alzado mi voz para rendir este homenaje en mi condición de legislador y, también, porque soy un profundo admirador de la sabia orientación que don Enrique Molina imprimió a esa casa de estudios.

No podría terminar mis observaciones de esta tarde sin antes señalar el papel específico que cumple la Universidad de Concepción. Sólo básteme indicar que el $50 \%$ de la utilidad que arroja la Lotería de Concepción, estimado en $\$ 156.000,000$ anuales, estimula las actividades de una serie de instituciones, entre las cuales se encuentran la Universidad de Chile, la Universidad Católica de Santiago, el Hospital Naval y Militar y la Cruz Roja Chilena, que son copartícipes de las utilidades a que me he referido. 
La Universidad de Concepción tiene 37 años de vida, esforzada y sacrificada al servicio de más de 2,000 alumnos de ambos sexos, venidos de diferentes lugares del territorio nacional. Este hecho habla por sí solo y prueba que no han sido inútiles tanto esfuerzo y abnegación y que la simiente generosa y fecunda no cayó en surco estéril. Y ahí está este centro de estudios con toda la majestad de su grandeza, instalado en una verdadera ciudad universitaria, orgullo de Concepción y de todo un pueblo que ve en ella el más alto exponente de sus virtudes.

Al término de mis observaciones, con las cuales he rendido un homenaje muy sincero al ex Rector de la Universidad de Concepción, solicito, señor Presidente, se sirva recabar el asentimiento de la Sala para que se haga llegar al distinguido catedrático don Enrique Molina, una nota de congratulación en nombre de la Honorable Cámara por los importantes servicios prestados en favor de la enseñanza universitaria y del país, en la esperanza que la actuación del nuevo Rector, señor David Stitchkin, continúe por la senda trazada por don Enrique Molina.

Nada más, señor Presidente.

El señor Carmona (Vicepresidente).-Solicito el asentimiento unánime de la Sala para enviar. en nombre de la Corporación, la nota a que se ha referido el Honorable señor Puente, don Adán.

("El Sur" de Concepción, 19 de mayo de 1956). 